\title{
Prenatal and postnatal correlated responses in maternal traits of mice assessed by crossfostering ${ }^{(1)}$
}

\author{
E.J. EISEN and T.R. BANDY (2) \\ Department of Animal Science, North Carolina State University \\ Box 7621, Raleigh, NC 27695-7621, U.S.A.
}

\begin{abstract}
Summary
A crossfostering design was used to estimate correlated responses in prenatal genetic and postnatal maternal effects for maternal traits of mice (female body weights at mating, at parturition and at 12-d postpartum, litter size and weight at birth, percent born alive, standardized (12 pups) 12-d litter weight and birth to 12-d litter feed efficiency $=$ litter weight gain/dam feed intake). Lines of mice had been selected as follows : large first-parity litter size at birth $(\mathrm{L}+)$; large 6-wk body weight $\left(\mathrm{W}^{+}\right)$; an index for large litter size and small 6-wk body weight $\left(\mathrm{L}^{+} \mathrm{W}^{-}\right)$and randomly $(\mathrm{K})$. Prenatal line refers to the line into which a female was born, and postnatal line is that of the foster mother that nursed the female. Crossfostering sets were formed at birth with equal numbers of pups from the 4 lines reared either in litters of 8 or 16 . Dams reared in litters of 8 were heavier, had larger litters at birth and larger litter weights at birth and 12-d postpartum $(\mathrm{P}<0.05)$. No biologically important interactions were found between number reared and prenatal genetic effects or between number reared and postnatal maternal effects. Selection for litter size at birth and (or) 6-wk body weight resulted in large correlated responses in maternal traits. Correlated responses in postnatal maternal effects were relatively small compared with prenatal genetic effects. Prenatal genetic by postnatal maternal interactions generally were not of biological importance. Postnatal maternal effects contributed much less to correlated responses in traits associated with reproduction and maternal performance compared with growth-related traits.
\end{abstract}

Key words : Correlated responses, maternal effects, reproductive traits, mice.

\section{Résumé}

Réponses corrélées pré- et post-natales sur des caractères maternels de la souris évaluées par un dispositif d'allaitement croisé

Un dispositif d'allaitement croisé a été utilisé pour estimer les réponses corrélées sur les effets génétiques prénataux et les effets maternels postnataux pour des caractères d'aptitude maternelle chez la souris (poids corporel de la femelle lors de l'accouplement,

(1) Paper No. 9963 of the Journal Series of the North Carolina Agricultural Research Service, Raleigh 27695. The use of trade names in this publication does not imply endorsement by the North Carolina Agricultural Research Service of the products named, nor criticism of similar ones not mentioned.

(2) Present address : Department of Animal Science, Purdue University, Lafayette, IN 47907. 
à la parturition et 12 jours post partum, taille et poids de la portée à la naissance, pourcentage de nés vivants, poids de portée à 12 jours standardisé (à 12 produits) et efficacité alimentaire de 0 à 12 jours définie comme le rapport du gain de poids de la portée à la consommation de la mère). Les lignées de souris utilisées ont été sélectionnées de la manière suivante : sélection pour une taille de portée élevée à la naissance en parité 1 $(\mathrm{L}+)$; sélection pour le poids corporel à 6 semaines $(\mathrm{W}+)$; sélection sur un index pour une taille de portée élevée et un faible poids corporel à 6 semaines $(\mathrm{L}+\mathrm{W}-$ ) et lignée témoin (K). Le terme de "lignée prénatale» désigne la lignée dans laquelle une femelle est née, celui de "lignée postnatale » la lignée de la mère adoptive qui allaite la femelle. Des groupes d'allaitement croisé ont été constitués à la naissance avec des nombres égaux de souriceaux issus des 4 lignées, élevés en portée de 8 ou de 16 . Les mères élevées en portées de 8 sont plus lourdes; les portées qu'elles produisent ont une taille plus élevée à la naissance, ainsi que des poids plus importants à la naissance et 12 jours post partum $(P<0,05)$. On n'a pas trouvé d'interactions biologiquement importantes entre la taille de portée d'origine et les effets génétiques prénataux, ni entre la taille de portée d'origine et les effets maternels postnataux. La sélection pour la taille de portée à la naissance et (ou) le poids corporel à 6 semaines entraîne d'importantes réponses corrélées sur les caractères maternels. Les réponses corrélées sur les effets maternels postnataux sont relativement faibles comparées à celles observées sur les effets génétiques prénataux. Les interactions entre les effets génétiques prénataux et les effets maternels postnataux ne sont en général pas biologiquement importantes. Les effets maternels postnataux contribuent beaucoup moins aux réponses corrélées sur les caractères associés à la reproduction et aux aptitudes maternelles qu'à celles observées sur les caractères liés à la croissance.

Mots clés : Réponses corrélées, effets maternels, caractères de reproduction, souris.

\section{Introduction}

Selection for increased reproductive performance has received considerable emphasis in pigs (Cunningham et al., 1979 ; Bichard \& Seidel, 1982 ; Bolet \& Legault, 1982), beef cattle (Piper \& Bindon, 1979 ; Morris, 1984), sheep (Hanrahan, 1982) and rabbits (MATHERON, 1982). Selection response depends upon variances of both direct and maternal breeding values and the covariance between them (VAN VLECK, 1970, 1973; HANRAHAN, 1976). Information on additive maternal genetic variance for reproductive traits and genetic correlations between maternal and direct genetic effects generally is lacking in livestock. Consequently, the expected correlated responses in maternal effects from selection for reproductive traits and indices that include reproductive traits are usually unknown.

In this study the mouse was used in a crossfostering design to estimate correlated responses in postnatal maternal and prenatal genetic effects on maternal traits in lines that had been selected for litter size and (or) body weight. Dams were reared in small (8) or large (16) litters to determine if litter size in which a dam was reared interacted with maternal and (or) prenatal genetic effects. In a previous paper, correlated responses were reported for progeny growth from the same crossfostering experiment (BANDY \& EISEN, 1984).

\section{Materials and methods}

Lines used in this study had been selected as follows (EISEN, 1978) : large first-parity litter size at birth $\left(\mathrm{L}^{+}\right)$; large 6 -wk body weight $\left(\mathrm{W}^{+}\right)$; an index for large 
litter size and small 6-wk body weight $\left(\mathrm{L}^{+} \mathrm{W}^{-}\right)$and randomly $(\mathrm{K})$. Selection had been practiced contemporaneously in each line for 23 generations and was followed by 10 generations of relaxed selection. No evidence of genetic slippage or inbreeding depression has been observed (HORSTGEN-SCHWARK et al., 1984).

The design of the crossfostering experiment was given previously (BANDY \& EISEN, 1984). Briefly, virgin males and females from generation 33 were randomly paired within lines. Beginning on day 19 after mating, females were checked daily at 0700 and $1500 \mathrm{~h}$ for littering. Crossfostering sets were formed by choosing 4 dams at random, one from each line, having littered within the same or adjacent periods. Sets were allocated alternately to litter standardization of 8 (LS8) or 16 (LS16) for a total of 40 sets for each litter size group. Crossfostering was accomplished by randomly assigning either one (in LS8) or 2 (in LS16) pups of each sex from each of the 4 litters to each of the dams in the set.

The crossfostering design provides estimates of a prenatal line effect $\left(a_{i}\right)$ and a postnatal line effect $\left(\mathrm{p}_{\mathrm{i}}\right)$. Prenatal line refers to the line into which an individual female was born, and postnatal line is the line of the dam that nursed the female. The present crossfostering design gave rise to 32 prenatal line by postnatal line by number reared subclasses.

Because of space limitations, half of the females within each subclass were assigned randomly to be mated at either 9 or 12 weeks of age. Mating pairs were randomly formed within each subclass. After 16 days of continuous cohabitation with a male, females were caged singly and subsequently checked twice daily for litters. The goal was to standardize litters to 12 pups on the day of birth, attempting to get, as nearly as possible, an equal sex ratio. Fostered individuals were used only within the same prenatal line by postnatal line by number reared subclass. Standardization to 12 pups was achieved in approximately 85 p. 100 of the 1050 litters.

The following traits were measured : dam body weights at mating, at parturition and at 12-days postpartum; litter size born; percentage born alive ; achieved number of pups standardized and number at 12 days postpartum; litter weight at birth before and after standardization, and at 12 days postpartum; dam feed intake from birth to 12-days postpartum; and litter feed efficiency defined as $100 \times$ litter weight gain/dam feed intake in the interval from birth to 12 days postpartum. Litter feed efficiency is a justified measurement because the pups' only source of nutrients during this interval is the dam's milk.

Dams had been fed ad libitum Purina Laboratory Chow from weaning until they were mated, at which time Purina Mouse Chow was fed ad libitum. The laboratory was maintained at $22 \pm 2 \mathrm{C}$ and $60 \pm 10$ p. 100 relative humidity with a 12-h light : 12-h dark cycle.

The least-squares analysis for unbalanced data was based on a statistical model that included the effects of age of dam, litter size in which the dam had been reared, crossfostering sets within litter size reared, prenatal line of dam, postnatal line of dam, interactions, experimental error and residual. All effects were assumed fixed except for sets, experimental error and residual effects which were assumed random. Litter size in which a dam was reared was tested by sets. All other fixed effects were tested with the experimental error, which was obtained by pooling all interactions involving sets. Interactions between fixed effects generally were not important. Covariates added to the model for some traits will be discussed in results. 


\section{Results}

\section{A. Age of dam}

Least-squares means for mating age of dams are given in table 1. Older dams were about 9 p. 100 larger $(P<0.05)$ at mating. The age difference in dam body weight was significant at parturition, but was not large enough to be considered of biological importance. No dam body weight difference was found at 12-days postpartum. Number born was about 4 p. 100 larger $(P<0.05)$ in older dams. The difference was significant $(\mathrm{P}<0.05)$ even after covariance adjustment for dam body weight at parturition ( $9 \mathrm{wk}=14.1$ vs $12 \mathrm{wk}=14.5$ ). Age of dam did not affect percentage born alive, litter weight at birth and at 12 days, or litter feed efficiency.

TABLE 1

Least-squares means at 2 mating ages of dams (1).

\begin{tabular}{|c|c|c|c|}
\hline \multirow{2}{*}{ Trait } & \multicolumn{2}{|c|}{ Age } & \multirow{2}{*}{$\begin{array}{l}\text { Approx. } \\
\text { stand. error }\end{array}$} \\
\hline & 9 wk & $12 \mathrm{wk}$ & \\
\hline \multicolumn{4}{|l|}{ Dam body weight $(\mathrm{g})$} \\
\hline Mating $\ldots \ldots \ldots \ldots \ldots \ldots \ldots \ldots$ & $30.1(a)$ & $32.9(b)$ & 0.11 \\
\hline Parturition $\ldots \ldots \ldots \ldots \ldots \ldots \ldots$ & $42.3(a)$ & $42.0^{(b)}$ & 0.14 \\
\hline 12-d postpartum $\ldots \ldots \ldots \ldots \ldots \ldots$ & $49.6(\mathrm{a})$ & 49.6 (a) & 0.18 \\
\hline \multicolumn{4}{|l|}{ Litter size } \\
\hline Birth (number) & $14.0(a)$ & $14.6(\mathrm{~b})$ & 0.16 \\
\hline Percent born alive & 95.1 (a) & $94.4(a)$ & 0.60 \\
\hline Achieved std. (number) & 11.4 & 11.6 & \\
\hline 12-d postpartum (number) & 11.2 & 11.4 & \\
\hline \multicolumn{4}{|l|}{ Litter weight $(\mathrm{g})$} \\
\hline Birth ....... & $21.7(a)$ & $22.4(\mathrm{a})$ & 0.23 \\
\hline Std. (2) & 18.7 (a) & 18.5 (a) & 0.06 \\
\hline 12-d postpartum & $79.4(a)$ & $78.9(a)$ & 0.50 \\
\hline Litter feed efficiency $(100 \mathrm{~g} / \mathrm{g})$ & $28.53(a)$ & 28.87 (a) & 0.20 \\
\hline
\end{tabular}

(1) There were 500 and 550 dams at 9 and $12 \mathrm{wk}$, respectively.

$(\mathrm{a}, \mathrm{b})$ Within a row, means with no superscripts in common are significantly different $(\mathrm{P}<0.05)$.

(2) Means adjusted by covariate, standardization achieved ; without covariate, means not significantly different. Without covariate, $R^{2}=0.33$, with covariate $R^{2}=0.82$.

\section{B. Litter size in which a dam was reared}

Dams reared in LS8 were larger $(\mathrm{P}<0.05)$ at mating $(10.3$ p. 100), parturition (7.1 p. 100) and 12-days postpartum (7.1 p. 100) than dams reared in LS16 (tabl. 2). Dams reared in the smaller litter size also had 8.0 p. 100 larger $(P<0.05)$ litters 
TABLE 2

Least-squares means by litter size in which a dam was reared (1).

\begin{tabular}{|c|c|c|c|}
\hline \multirow{2}{*}{ Trait } & \multicolumn{2}{|c|}{ Litter size } & \multirow{2}{*}{$\begin{array}{l}\text { Approx. } \\
\text { stand. error }\end{array}$} \\
\hline & LS 8 & LS 16 & \\
\hline \multicolumn{4}{|l|}{ Dam body weight (g) } \\
\hline Mating $\ldots \ldots \ldots \ldots \ldots \ldots \ldots \ldots \ldots$ & $33.2(a)$ & $29.8^{(b)}$ & 0.11 \\
\hline Parturition $\ldots \ldots \ldots \ldots \ldots \ldots \ldots \ldots$ & 44.2 (a) & 40.9 (b) & 0.14 \\
\hline 12-d postpartum $\ldots \ldots \ldots \ldots \ldots \ldots \ldots$ & $51.6^{(a)}$ & 47.5 (b) & 0.18 \\
\hline \multicolumn{4}{|l|}{ Litter size } \\
\hline Birth (number) & 14.9 (a) & $13.6(b)$ & 0.16 \\
\hline Percent born alive & 95.1 (a) & 94.4 (a) & 0.67 \\
\hline Achieved std. (number) & 11.6 & 11.4 & \\
\hline 12-d postpartum (number) & 11.4 & 11.2 & \\
\hline \multicolumn{4}{|l|}{ Litter weight (g) } \\
\hline Birth & 22.7 (a) & $21.4(\mathrm{~b})$ & 0.23 \\
\hline Std. (2) & 18.5 (a) & $18.7(b)$ & 0.06 \\
\hline 12-d postpartum & $80.3^{\text {(a) }}$ & $78.0^{(b)}$ & 0.50 \\
\hline Litter feed efficiency $(100 \mathrm{~g} / \mathrm{g}) \ldots$ & 28.9 (a) & $28.5(\mathrm{a})$ & 0.18 \\
\hline
\end{tabular}

(1) There were 550 and 500 dams for litter size 8 and 16, respectively.

(a, b) Within a row, means with no superscripts in common are significantly different $(\mathrm{P}<0.05)$.

(2) Means adjusted by covariate, standardization achieved ; without covariate, means not significantly different. Without covariate, $R^{2}=0.33$, with covariate $R^{2}=0.82$.

at birth and 5.6 p. 100 larger litter weights at birth and 2.4 p. 100 larger litter weights at 12-days postpartum. When number alive at 12 days was used as a covariate, the litter weight difference at 12 days was still significant $(P<0.05)$. The effect of litter size in which a dam was reared did not significantly influence litter size born when adjusted for dam parturition body weight (LS8 $=14.4$ vs LS16 $=14.1)$. Percentage born alive and litter feed efficiency were not affected by the litter size in which a dam was reared.

\section{Prenatal genetic $\left(a_{i}\right)$ and postnatal maternal genetic $\left(p_{i}\right)$ effects}

Prenatal line effects were more important than postnatal line effects for dam body weights (tabl. 3). Prenatal line differences for dam body weight at mating were similar to prenatal line differences for 6-wk body weight (BANDY \& EISEN, 1984). The correlated responses in prenatal line effects for dam body weight were maintained at parturition and 12-days postpartum in $\mathrm{L}^{+}$and $\mathrm{W}+$, but $\mathrm{L}+\mathrm{W}-$ showed no significant correlated responses at these stages of reproduction. Correlated responses in postnatal line effects for dam body weight at joining were positive $(\mathrm{P}<0.05)$ for $\mathrm{W}^{+}$and negative $(\mathrm{P}<0.05)$ for $\mathrm{L}^{+} \mathrm{W}^{-}$, but only in $\mathrm{L}^{+} \mathrm{W}^{-}$was the correlated response maintained for dam body weights at parturition and 12-days postpartum. 
TABLE 3

Least-squares means of dam body weight by prenatal and by postnatal line (1).

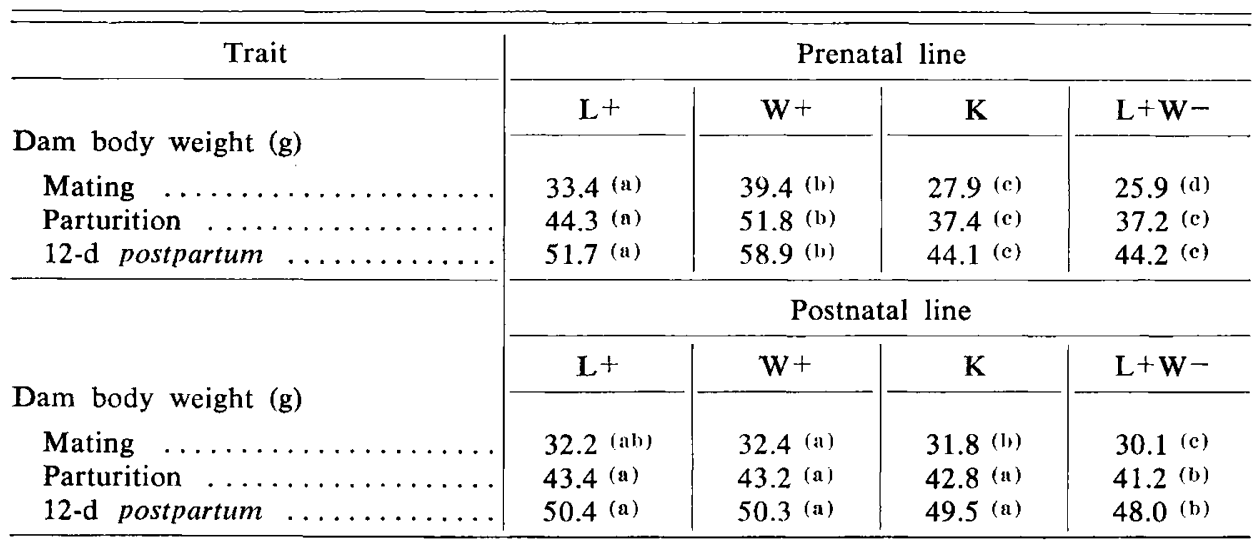

$(a, b, c, d)$ Within a row, means with no superscripts in common are significantly different $(P<0.05)$. (1) Pooled across dam age and litter size in which a dam was reared.

Correlated responses in prenatal genetic and postnatal maternal effects for each selected line are graphed for the reproductive and postpartum traits as deviations from the control line and pooled across dam age and litter size in which a dam was reared (fig. $1 \mathrm{AE}$ ). The pooling was justified because interactions were negligible. Positive correlated responses in $a_{i}$ for litter size born and litter birth weight were found for $\mathrm{L}^{+}, \mathrm{W}^{+}$and $\mathrm{L}^{+} \mathrm{W}^{-}$, whereas negative correlated responses were observed for percent born alive. For 12-day litter weight, $a_{i}$ increased in $L^{+}$and $W^{+}$, but decreased in $\mathrm{L}+\mathrm{W}-$. Correlated responses in $\mathrm{a}_{\mathrm{i}}$ for litter feed efficiency were positive in $\mathrm{L}+$ and negative in $\mathrm{L}+\mathrm{W}^{-}$.

Lines $\mathrm{L}^{+}$and $\mathrm{W}+$ had no significant correlated responses in $\mathrm{p}_{\mathrm{i}}$ for any of the reproductive traits. Litter size born and 12-day litter weight in $\mathrm{L}+\mathrm{W}-$ were the only significant (negative) correlated responses in $\mathrm{p}_{\mathrm{i}}$. The correlated response in 12-day litter weight was not affected by the covariance adjustment for number at 12 days.

Standardized measures of the among-line variation in prenatal genetic and postnatal maternal effects can be used to assess their relative importance. The effects of within-line variation on a mean basis were assumed negligible because of large within-line sample size. The relative among-line variation in estimates of $a_{i}$ and $p_{i}$ for each trait was defined as :

and

$$
\Phi_{a}=100 \quad\left[\sum_{i=1}^{n} a_{i}^{2} /(n-1)\right]^{\frac{1}{2}} / \bar{X}_{k}
$$

$$
\Phi_{\mathrm{p}}=100\left[\sum_{\mathrm{i}=1}^{\mathrm{n}} \mathrm{p}_{\mathrm{i}}^{2} /(\mathrm{n}-1)\right]^{\frac{1}{2}} / \mathrm{X}_{\mathrm{k}}
$$

where $\sum_{i=1}^{n} a_{i}^{2} /(n-1)$ and $\sum_{i=1}^{n} p_{i}^{2} /(n-1)$ are estimates of the respective among- 
line prenatal genetic and postnatal maternal variances, $\bar{X}_{k}$ is the control line mean and $n$ is the number of lines. The ratio $\Phi_{a} / \Phi_{p}$ represents an estimate of the relative importance of prenatal genetic compared with postnatal maternal among-line variation. Results of this analysis are given in table 4. Estimates of $\Phi_{a}$ were considerably larger than $\Phi_{\mathrm{p}}$ for all maternal traits.

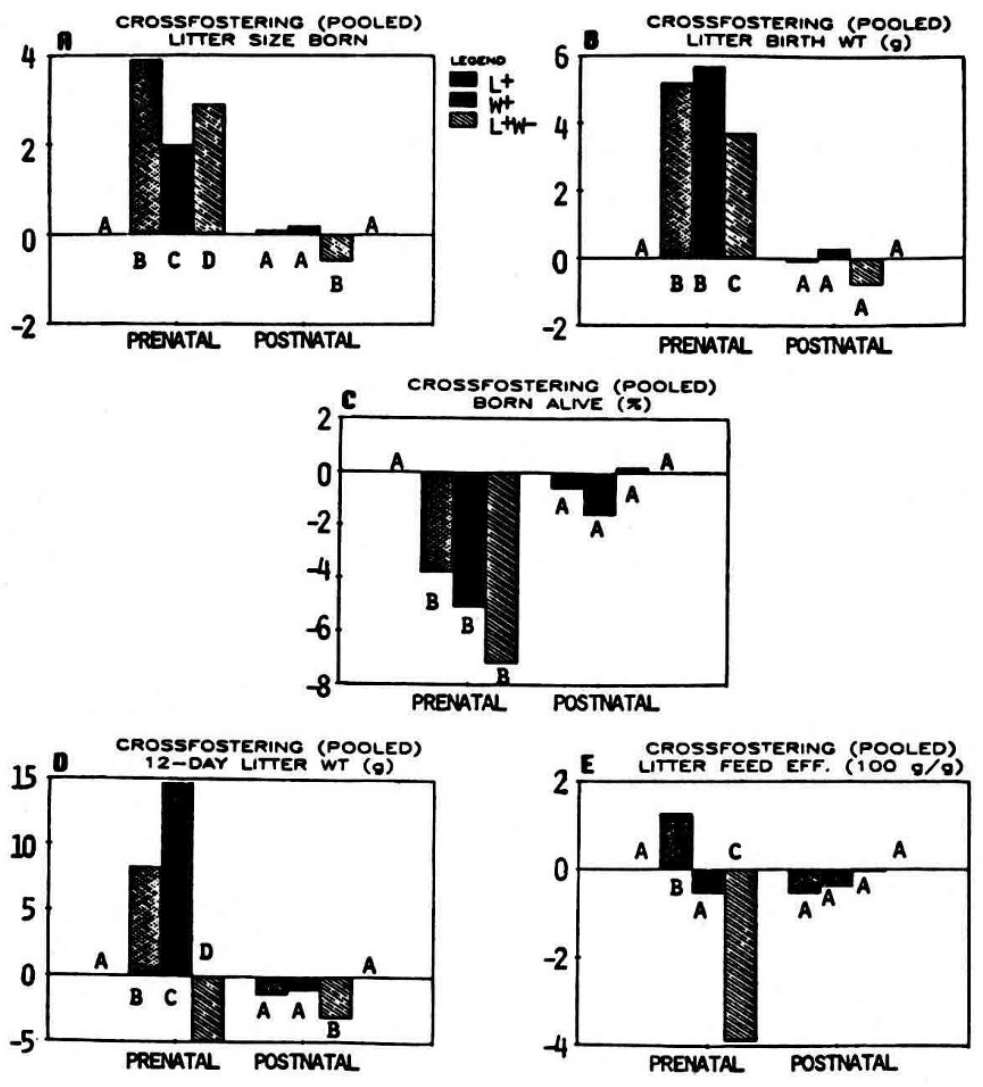

FIG. 1 A-E

Correlated responses in prenatal genetic and postnatal maternal genetic effects, as deviations from control line effects.

Within prenatal and within postnatal effect comparisons,

the effects with no letters in common $(A, B, C, D)$ are different $(P<0.05)$.

The left-and right-most letters represent the control line for prenatal and postnatal effects, respectively.

The correlated responses are pooled over litter size in which a dam was reared and age of dam. 
Negative correlations between prenatal genetic and postnatal maternal effects can affect the choice of breeds for a breeding system. The present data were used to calculate the correlation between the among-line prenatal genetic and postnatal maternal genetic effects, defined as :

$$
r_{a p}=\sum_{i=1}^{n} a_{i} p_{i} /\left[\left(\sum_{i=1}^{n} a_{i}^{2}\right)\left(\sum_{i=1}^{n} p_{i}^{2}\right)\right]^{\frac{1}{2}}
$$

Although the number of lines was not large enough to provide a precise estimate of $r_{a p}$, the data do provide a general picture of the degree of possible antagonisms. Within this set of selection criteria there was no evidence of any serious antagonisms for traits of the dam (tabl. 4).

\section{TABLE 4}

Relative prenatal genetic $\left(\Phi_{a}\right)$ and postnatal maternal genetic $\left(\Phi_{p}\right)$ variation among lines and correlation $\left(r_{a p}\right)$ between prenatal and postnatal line effects.

\begin{tabular}{|c|c|c|c|c|}
\hline Trait & $\Phi_{\mathrm{a}}$ & $\Phi_{\mathrm{p}}$ & $\Phi_{\mathrm{a}} / \Phi_{\mathrm{p}}$ & $r_{\text {ap }}$ \\
\hline \multicolumn{5}{|l|}{ Dam body weight (g) } \\
\hline Mating $\ldots \ldots \ldots \ldots$ & 21.6 & 3.7 & 5.8 & 0.79 \\
\hline Parturition & 18.4 & 2.7 & 6.8 & 0.65 \\
\hline 12-d postpartum & 16.1 & 2.5 & 6.4 & 0.74 \\
\hline Litter size born & 13.7 & 2.8 & 4.9 & -0.37 \\
\hline Litter birth wt (g) & 14.0 & 2.5 & 5.6 & 0.12 \\
\hline Born alive $(\%)$ & 3.1 & 0.8 & 3.9 & 0.13 \\
\hline 12-d litter wt (g) & 12.7 & 1.8 & 7.1 & 0.46 \\
\hline Litter feed efficiency $(100 \mathrm{~g} / \mathrm{g})$ & 7.4 & 0.9 & 8.2 & -0.35 \\
\hline
\end{tabular}

\section{Discussion}

Expected direct response to individual selection depends upon direct and maternal heritabilities and the genetic correlation between direct and maternal effects. For correlated responses, this expectation depends upon the genetic correlations between direct effects, between maternal effects and between direct and maternal effects for the selected and unselected traits. Often, the entire suite of genetic parameters are not known well enough to make accurate predictions. Therefore, as a first approximation, the maternal parameters usually are ignored in determining predicted direct and correlated responses to selection.

The present study used the crossfostering design to examine the importance of postnatal maternal correlated responses in retrospect ; i.e, after the selection experiment was completed. Lines of mice had been selected for growth (large 6-wk body 
weight), reproduction (large litter size) and an index (large litter size and small body weight) antagonistic to the positive genetic correlation $\left(r_{G}=.5\right)$ between litter size and adult body weight (EISEN, 1978).

Selection for litter size at birth and (or) 6-wk body weight resulted in large correlated responses in reproductive and maternal traits. Correlated responses in postnatal maternal genetic effects were relatively small compared with prenatal genetic effects. This contrasts with individual growth traits through weaning, estimated from the same crossfostering study (BANDY \& EISEN, 1984). For example, among-line variation was approximately equal for postnatal maternal genetic and prenatal genetic effects on weaning weight of progeny reared in litters of 8 , and postnatal maternal genetic variation was 2.76 times greater than prenatal genetic effects in progeny reared in litters of 16. Prenatal genetic effects were more important than postnatal maternal genetic effects for 6-wk body weight (BANDY \& EISEN, 1984), but the ratio of $\Phi_{a} / \Phi_{p}$ was smaller than for dam body weights at mating, parturition and 12-days postpartum. The conclusion from this study and others using these lines (BANDY \& EISEN, 1984 ; EISEN et al., 1984 ; HorSTGEN-SCHWARK et al., 1984) is that postnatal maternal effects are much less important in determining correlated responses in traits associated with reproduction and maternal performance compared with growth-related traits.

WHITE et al. (1968) used the same crossfostering design to study correlated responses in traits of the dam in lines selected for large and small 6-wk body weight. In agreement with the present study, prenatal genetic effects were more important than postnatal maternal effects. Selection for large 6-wk body weight resulted in a significant positive correlated response in prenatal genetic effects on litter size although the effect was much smaller than that observed in the present study. In contrast with the present study, 12-day litter weight showed a negative correlated response for prenatal effects in a line selected for large 6-wk body weight.

The absence of large negative correlations between prenatal genetic and postnatal maternal effects for dam traits suggests that in selection among these lines or lines having a similar history of selection, antagonisms between prenatal genetic and postnatal maternal effects would not be expected for maternal traits. These correlations are a function of the selection criteria applied to the lines and cannot be extrapolated to other sets of lines.

There were no biologically important interactions of prenatal genetic by postnatal maternal, prenatal genetic by number reared, postnatal maternal by number reared or prenatal genetic by postnatal maternal by number reared effects. Interactions that were significant generally were the result of a change in magnitude of mean differences rather than a change in ranking of means. Similar results were observed for growth traits of the progeny (BANDY \& EISEN, 1984). Absence of prenatal line by postnatal line interactions indicates that fostering effects per se were relatively unimportant. Lack of significant prenatal line by number reared and postnatal line by number reared interactions suggests that correlated responses in reproductive and maternal traits were nominally affected by the size of the litter in which the dam was reared.

In general, the estimated correlated responses for prenatal and postnatal maternal genetic effects were in agreement with estimates from a diallel design using the same lines (EISEN et al., 1984 ; HORSTGEN-SCHWARK et al., 1984). There were, however, some specific differences in correlated responses for the corresponding estimates in 
the diallel design $\left(\mathrm{p}_{\mathrm{i}}\right.$ vs $\left.\mathrm{m}_{\mathrm{i}}\right)$ and the crossfostering design $\left(\mathrm{a}_{\mathrm{i}}\right.$ vs $\left.\Omega_{\mathrm{i}}\right)$ (EISEN et al., 1985), where $p_{i}$ and $a_{i}$ are as defined previously, and $m_{i}$ and $\Omega_{i}$ are the average line maternal and line direct genetic effects as defined in the diallel design (EISEN et al., 1984).

Part of the reason for the observed differences could be caused by differences in biological expectation of the estimates from each design (BANDY \& EISEN, 1984). Assuming a model with no paternal effects and no interactions among effects, the maternal and direct genetic effects for line $\mathrm{i}$ in a diallel design have expectations

and

$$
\mathrm{E}\left(\mathrm{m}_{\mathrm{i}}\right)=\mathrm{M}_{\mathrm{i}}+\mathrm{U}_{\mathrm{i}}+\mathrm{C}_{\mathrm{i}}
$$

$\mathrm{E}\left(\Omega_{\mathrm{i}}\right)=A_{\mathrm{i}}$,

whereas the postnatal maternal genetic and prenatal effects in a crossfostering design have expectations

and

$$
E\left(p_{i}\right)=M_{i}
$$

$$
E\left(a_{i}\right)=A_{i}+U_{i}+C_{i},
$$

where

$\mathrm{E}$ is the expected value operator,

$\mathbf{M}_{\mathrm{i}}$ = average postnatal (lactational and/or behavioral) maternal genetic effects,

$\mathbf{U}_{\mathbf{i}}=$ average prenatal (intrauterine) maternal genetic effects,

$\mathrm{C}_{\mathrm{i}}=$ average cytoplasmic and (or) pathogen or antibody transmitted maternal effects and

$$
A_{i}=\text { average direct genetic effects. }
$$

From the above expectations, it is possible to obtain only 2 confounded estimates of uterine and cytoplasmic effects

$$
\mathrm{m}_{\mathrm{i}}-\mathrm{p}_{\mathrm{i}}=\mathrm{a}_{\mathrm{i}}-\Omega_{\mathrm{i}}=\mathrm{U}_{\mathrm{i}}+\mathrm{C}_{\mathrm{i}} \text {. }
$$

While it is tempting to use the present data to estimate $U_{i}+C_{i}$, it is inappropriate because the 2 designs were confounded with time effects and the number of generations of relaxed selection. Also, dams were reared in litters of eight in the diallel design while dams in the crossfostering design were reared in litters of 8 or 16 . For postpartum performance traits, litters were not standardized in the diallel design, but were in the crossfostering design.

Uterine maternal effects on growth have not been detected in mice beyond 2 weeks of age, and even at 2 weeks uterine effects are not as large as postnatal maternal or direct genetic effects (Moore et al., 1970 ; Al-Murrani \& RoberTs, 1978). The role that cytoplasmic maternal effects has on quantitative traits in animals is just beginning to be investigated. BELL et al. (1985) reported cytoplasmic effects for first lactation milk yield, milk fat yield, fat-corrected milk yield and milk fat percentage in dairy cattle. Because mitochondria play a key role in electron transport and oxidative phosphorylation, they are a prime candidate for cytoplasmic maternal effects contributing to selection response. Maternal effects associated with selection of maternally transmitted antibodies or pathogens may also affect selection responses. MAYER et al. (1980) found maternal transmission of resistance to lymphoma development in reciprocal crosses of 2 strains of mice. HARRIS (1982) has shown that a congenitally 
transmitted virus from dam to offspring can modify selection response in poultry. Further studies are needed to determine the importance of cytoplasmically transmitted maternal effects on metric traits.

Received June 26, 1985.

Accepted December 10, 1985.

\section{References}

Al-Murrani W.K., Roberts R.C., 1978. Maternal effects on body weight in mice selected for large and small size. Genet. Res., 32, 295-302.

BANDY T.R., Eisen E.J., 1984. Prenatal and postnatal effects in mouse lines selected for body weight and litter size : Performance of postnatal dams and growth of progeny. J. Anim. Sci., 59, 896-907.

Bell B.R., McDaniel B.T., Robison O.W., 1985. Effects of cytoplasmic inheritance on production traits in dairy cattle. J. Dairy Sci., 68, 2038-2051.

Bichard M., SEIDEL C.M., 1982. Selection for reproductive performance in maternal lines of pigs. Second World Congress on Genetics Applied to Livestock Production, Vol. VIII, 565-569, Editorial Garsi, Madrid.

Bolet G., Legault C., 1982. New aspects of genetic improvement of prolificacy in pigs. Second World Congress on Genetics Applied to Livestock Production, Vol. V, 548-567, Editorial Garsi, Madrid.

Cunningham P.J., England M.E., Young L.D., Zimmerman D.R., 1979. Selection for ovulation rate in swine : Correlated response in litter size and weight. J. Anim. Sci., 48, 509-516.

EISEN E.J., 1978. Single-trait and antagonistic index selection for litter size and body weight in mice. Genetics, 88, 781-811.

Eisen E.J., Horstgen-Schwark G., Bandy T.R., Saxton A.M., 1984. Postpartum performance in a diallel cross among lines of mice selected for litter size and body weight. J. Anim. Sci., 58, 863-877.

Eisen E.J., Bandy T.R., Horstgen-Schwark G., SaXton A.M., 1985. Correlated responses in maternal effects caused by single trait or antagonistic index selection for litter size and body weight in mice. Proc. 34th Annual National Breeders' Roundtable. Poultry Breeders of America, 31-63, St. Louis, MO.

HanRahan J.P., 1976. Maternal effects and selection response with an application to sheep data. Anim. Prod., 22, 359-369.

HanRahan J.P., 1982. Selection for increased ovulation rate, litter size and embryo survival. Second World Congress on Genetics Applied to Livestock Production, Vol. V, 294-309, Editorial Garsi, Madrid.

HaRris D.L., 1982. Congenitally transmitted pathogens and their consequences in animal and poultry breeding. Second World Congress on Genetics Applied to Livestock Production, Vol. V, 175-185, Editorial Garsi, Madrid.

Horstgen-Schwark G., Eisen E.J., Saxton A.M., Bandy T.R., 1984. Reproductive performance in a diallel cross among lines of mice selected for litter size and body weight. J. Anim. Sci., 58, 846-862.

Matheron G., 1982. Genetics and selection of litter size in rabbit. Second World Congress on Genetics Applied to Livestock Production, Vol. VI, 481-498, Editorial Garsi, Madrid. 
Mayer A., Struuck F.D., Duran-Reynals M.L., Lilly F., 1980. Maternally transmitted resistance to lymphoma development in mice of reciprocal crosses of the $R F / J$ and AKR/J strains. Cell, 19, 431-436.

MoORe R.W., Eisen E.J., Ulberg L.C., 1970. Prenatal and postnatal maternal influence on growth in mice selected for body weight. Genetics, 64, 59-68.

Morris C.A., 1984. A Review of the genetics and reproductive physiology of dizygotic twinning in cattle. Anim. Br. Abstr., 52, 803-819.

PIPER L.R., Bindon B.M., 1979. Selection for increased cow fecundity : A review Proc. New Zealand Soc. Anim. Prod., 39, 224-232.

VAN VLECK L.D., 1970. Index selection for direct and maternal genetic components of economic traits. Biometrics, 26, 477-483.

Van Vleck L.D., 1973. Selection for direct and maternal genetic effects. In BogarT R. (ed.), Genetics Lectures, 133-148, Oregon State Univ. Press, Corvallis.

White J.M., Legates J.E., EISEN E.J., 1968. Maternal effects among lines of mice selected for body weight. Genetics, 60, 395-408. 